\title{
The Pursuit of Inner Peace-The Modernistic Narration in Katherine Mansfield's Short Stories
}

\author{
Zhang Lina ${ }^{1, a,{ }^{*}}$, Wang Shanshan ${ }^{2, b}$ \\ 1 Dalian Neusoft University of Information, Dalian, Liaoning, China \\ ${ }^{2}$ Dalian Neusoft University of Information, Dalian, Liaoning, China \\ azhanglina@neusoft.edu.cn, bwangshanshan@neusoft.edu.cn \\ *Corresponding author: Zhang Lina
}

Keywords: Modernistic narration, Inner peace, Katherine Mansfield, Short stories.

\begin{abstract}
Katherine Mansfield innovatively applies the modernistic narrative techniques to her creation of short stories to fill her works with poetic artistic charm. The paper aims at exploring her emphasis on the characters' pursuit of their inner peace in the short stories through modernistic narration techniques like plotless writing, stream of consciousness and interior monologue.
\end{abstract}

\section{Introduction}

In an era characterized by industrialization, rapid social change, advances in science and the social sciences, Modernists felt a growing alienation incompatible with Victorian morality, optimism, and convention. Undoubtedly, the crisis of the society and the spiritual trauma of people led to a great change in literary world. "It is one of the great and flourishing periods of writing, a time when the novel changed wonderfully in spirit and purpose" (Bradbury $v$ ). Writers turned their focus onto the inner world and individuality of ordinary human beings. Therefore, either in form or in content, the literary works of this period broke the bondage of time and space and described the changing consciousness of people.

Katherine Mansfield, a famous modernistic female writer, is no exception who established her literary fame on the short story writing. It's universally acknowledged that her life "was a small and sad legend of loss, romantic illness, and talent unfulfilled” (Robinson 1). Katherine Mansfield's modernistic narration takes on the features of poetry and focuses on the pursuit of the peaceful mood and inner world of the characters by utilizing the techniques of plotless story-telling, stream of consciousness and interior monologue.

\section{Literary review of Katherine Mansfield}

Katherine Mansfield's fame as a significant literary figure was not established until her death. Some critics claim that she is just an imitator of Chekhov. Many critics almost totally erase her from the development of modernist fiction. Michael Levenson does not even mention Katherine Mansfield in his influential book A Genealogy of Modernism. The situation is almost the same in Louis MeNand's Discovering Modernism. However, she is also approved by critics like David Daiches and Kaplan owing to her contribution to the form and techniques of the short stories. And Ian Gordon once remarks: "She had the same kind of directive influence on the art of the short story as Joyce had on the novel. After Joyce and Katherine Mansfield neither the novel nor the short story can ever be quite the same again” (qtd. in Kaplan 1).

Quite many scholars argue Mansfield's feministic ideas in her works, and examine the influence and status of them from this aspect. Sydney Janet Kaplan figures out that Katherine Mansfield's early works tend to fight for equal rights for women, and her later works focus on the exploration of sexual consciousness and identity of women. In Elaine Showalter's A Literature of Their Own, she also studies Mansfield from the feminism view. 
Mansfield's works are also studied from some other perspectives like psychological analysis, colonial criticism and stylistics. Pamela Dunbar's Double Discourse in Katherine Mansfield's Short Stories is the representative of these studies. In this book, the author employs psychological analysis and sociology to study Mansfield's works and believes that the story writer is influenced by the theory of Freud. She also regards Mansfield's short stories as psychological stories.

From the late 1980s, Chinese scholars began to pay attention to Mansfield's works and more critical reviews gradually appeared. Scholars in our country tended to focus on the relationship between the writer and her writing at the beginning; later deeper social meaning and her writing style were discussed. The study on Mansfield's identity background, feminism, regional complex, and so on also began to flourish in recent years.

\section{The pursuit of the inner peace}

As Michael Bell puts it: "The relative status of the human was a central recognition of Modernism itself” (Bell 13). Katherine Mansfield is quite interested in what her characters feel as individuals. In her stories the level of subtlety and psychological insight is striking. Therefore, her short stories have usually viewed as psychological works, for they involve so much of people's inner world by employing the approaches of plotless story-telling, stream of consciousness, inner monologue, shift of time and space.

\subsection{Plotless story-telling}

Katherine Mansfield is believed to be "a pioneer in the art of telling a short story about nothing and creating an unforgettable atmosphere" (Mais 113). "Plotless," is one of the modernistic characteristics of Mansfield's short stories. Plot is the series of events that takes us from a beginning to an end. Each event in the plot is related to the conflict, the struggle that the main character undergoes.

Unlike the traditional story consisting of such four parts as rising action, climax, falling action and denouement, "Miss Brill”, one of the well-known short stories written by Katherine Mansfield, just depicts old Miss Brill spending one of her afternoon in a little park and experiences the ebb and flow in her heart. Similar in "Life of Ma Parker," there is just several dialogues between the literary gentleman and Ma Parker, Mansfield reveals Ma Parker's bitter life through her recollection of the past. "At the Bay" is an illustrative example to her application and mastery of plotless story.

Many of Mansfield's short stories are like the composition of the pictures of life. There is no complicated incident, no climax and no twisted ending. It seems that each episode has nothing to do with a theme; however every episode coheres and reflects a same theme in true life. "A fiction survives, not by leading us anywhere, but by being at every point authentic, a recreation of life, so that we experience it and remember it as we experience and remember actual life. It has a multiple texture, like the texture of life itself”' (Stead 162).

\subsubsection{Plotless opening}

Katherine Mansfield's works usually start with scenes, either picturesque description or scenic descriptions of characters. Mansfield's attempt at plotlessness can be seen at the opening part of her short stories. It seems that her stories begin in the middle of things, without troubling to set the scene through a clarifying introduction. Readers immediately enter the scene she creates as a participator. Her typical plotless opening was vividly represented by her stories like "At the Bay” "The Baron”, "Carnation”, "just unfolds and opens" and "A Dill Pickle”, purely describing the scenery to create the peaceful inner society not only for the characters but also for the readers, and effectively shortens the distance between the characters and readers and makes their own involvement.

\subsubsection{Plotless ending}

The endings of Mansfield's short stories are also strong proof of her attempt at "plotlessness." The "neat 'finality' of the traditional endings" seems for Mansfield is "to convey the misleading notion of something finished, absolute, and wholly understood" (qtd. in Fullbrook 33). In her stories, no conclusion is drawn; no consummation of an event ever appears. There seems to be no so-called 
denouement in her endings. That is why her stories end either with exterior description of scenery like "Bank Holiday" and "At the Bay", or with ongoing dialogues, actions or even thoughts like "Sun and Moon”. Katherine Mansfield's stories are ended in this way: the conclusion to each of these narratives is neither a definitive nor an easy solution to the complex issues raised.

\subsection{Stream of consciousness}

Stream of Consciousness is a literary technique in which a character's thoughts are presented in the confusing, jumbled, and inconsequential manner of real life without any clarification by the author. It is a complex and difficult new technique innovated in Modern time. In some of Mansfield's stories, she has adopted the similar technique to express a character's consciousness.

Mansfield "writes only to tell the truth-not the truth for the outsider, for the observer who watches the action from the street corner, but the truth for the characters themselves and so the real meaning of the situation" (Daiches 32). In reality, a person's consciousness cannot just focus on one point. On the contrary, it is a shifting thing without stop flowing. In people's mind, there will be the to-and-fro in time and space. Mansfield employs the intercrossing of time and space in her many works. In “An Ideal Family” Katherine Mansfield describes Mr. Neave's flow of consciousness during his way back home, feeling, recollection, association and imagination vividly depicted and fully fulfilled in the part.

When expressing the stream of consciousness, Mansfield also notices the appearance of illusion in the mind of the characters at a certain moment to embody the character's inner world. As in the "An Ideal Family", Mr. Neave's illusion appears when he wakes up in vague thoughts: "A dark porch, half hidden by a passion-vine, that drooped sorrowful, mournful, as though it understood. Small, warm arms were round his neck. And "her innovations in the short-fiction genre especially lie in "the 'plotless' story, the incorporation of the 'stream of consciousness' into the content of fiction, and the emphasis on the psychological 'moment'” (Kaplan 3).

\subsection{Interior monologue}

Katherine Mansfield's characters tend to expose themselves through a more direct and straightforward way-interior monologue. Interior monologue is the written representation of a character's inner thoughts, impressions, and memories as if directly 'overheard' without the apparent intervention of a summarizing and selecting narrator. Katherine Mansfield is an adept at exploring her character's inner heart by interior monologue, which Mansfield in her later works "employs as her primary mode of narration” (Kobler 8).

3.3.1 Direct interior monologue

Several of Mansfield's works are written totally employing the approach of interior monologue. “'Two Tuppenny Ones, Please' is a monologue with a silent interlocutor; 'Late at Night' is pure monologue; 'The Black Cap' is mainly monologue except for a few brief exchanges with the stolid husband" (Hanson and Gurr 54). Her skillful use of the direct interior monologue is well embodied in "Late at Night." In this work, neither does the author herself at any point of view involve in narrating, nor is a single sentence used to talk to readers. It is the total openness of the character's inner world without any interference. Without any illustration or explanation of the author, readers can clearly see and feel the despair of the woman who lost her love. The reason for the character to begin her thoughts is that she has received a letter, in which a man tactfully refused her. We can see there involves slight flow of the character's consciousness, but the character's thoughts are logical and focusing, which is the slight difference between stream of consciousness and direct interior monologue.

\subsubsection{Indirect interior monologue}

Sometimes Katherine Mansfield "refuses to sacrifice her powers of independent observation, but at the same time she takes note of nothing which is not in the highest sense relevant to the situation she is presenting” (Daiches 40). Therefore, indirect interior monologue becomes an inevitable writing technique in her stories. Different from direct interior monologue, indirect interior monologue keeps the involvement of the author-readers can feel that they are led by the author through description 
and explanation. Indirect interior monologue employs the third person point of view instead of first person point of view, which will express one's inner world with the explanation of the author. In this way, readers can catch the floating of the character's consciousness; meanwhile the character's monologue logically becomes more coherent. Stories like "The Little Governess," "Pictures” and "An Ideal Family" all involve the indirect interior monologue.

"The Lady's Maid" is the most typical short story with the whole text being led by indirect interior monologue. The story is made up of a dialogue. However, the author only picks one side whereas the responses of the other side are totally skipped. The dialogue by the maid can be regarded as interior monologue; however, because of the existence of the undefined figure without whom the dialogue cannot be elicited, the monologue is accepted as indirect interior monologue. The narrative technique is applied to enable the characters to externalize their thoughts so that their peaceful internal world can be fully acquired by the readers.

\section{Summary}

With the linear structure of time or space sequence having been broken, modernist writers begin to arrange stories in accordance with the flow of the consciousness of the characters to set up a radiating structure and further to pursue the inner peacefulness of the characters. As a member living in Modern time, Katherine Mansfield has interpreted the modernistic characteristics in her works incisively and vividly. Her skillful adoption of modernistic narrative techniques such as plotless writing, stream of consciousness, interior monologue all reflect her impelling on the development of Modernism in literature. This weakening of plot along with the adoption of stream of consciousness and interior monologue is a strong proof not only of her innovative status but also of her great attention to people's inner world, because she applies these techniques to create stories based on the illumination of character rather than the development of plot, which can fully demonstrate her modernity and contributions to the reformation of short stories in techniques.

\section{References}

[1] Bell, Michael. “The Metaphysics of Modernism.” The Cambridge Companions to Modernism. Ed. Michael Levenson. Shanghai: Shanghai Foreign Language Education Press, 2000. 9-32.

[2] Bradbury, Malcolm. Preface. The Modern British Novel 1878-2001. By Malcolm Bradbury. Beijing: Foreign Language Teaching and Research Press, 2004. i - x iii.

[3] Daiches, David. “Katherine Mansfield.” The Critical Response to Katherine Mansfield. Ed. Jan Pilditch. London: Greenwood Press, 1996. 32-41

[4] Fullbrook, Kate. Katherine Mansfield. Sussex: The Harvest press, 1986.

[5] Hanson, Clare, and Andrew Gurr. Katherine Mansfield. London: The Macmillan Press Ltd, 1981.

[6] Kaplan, Sydney Janet. Katherine Mansfield and the Origins of Modernist fiction. New York: Cornell University Press, 1991.

[7] Kobler, J. F.. Katherine Mansfield: A Study of the Short Fiction. Boston: Twayne Publishes, 1990.

[8] Mais, S. P. B.. “Katherine Mansfield.” Critical Essays on Katherine Mansfield. Ed. Rhoda B. Nathan. New York: G. K. Hall \& Co., 1993. 113-116. 